КРАСОВСКАЯ Наталия Рудольфовна - кандидат психологических наук, Аппарат Государственной Думы ФС РФ (125007, Россия, г. Москва, ул. Охотный ряд, 1; goulina@gmail.com)

ГУЛЯЕВ Андрей Анатольевич - кандидат философских наук, доцент Московского государственного университета технологий и управления им. К.Г. Разумовского (ПКУ) (109004, Россия, г. Москва, ул. Земляной Вал, 73; andrey.gulyaev1966@yandex.ru)

ЮЛИНА Галина Николаевна - кандидат педагогических наук, доцент; директор Института социально-гуманитарных технологий Московского государственного университета технологий и управления им. К.Г. Разумовского (ПКУ) (109004, Россия, г. Москва, ул. Земляной Вал, 73; UlinaGN @ mgutm.ru)

\title{
ФЕЙКОВЫЕ НОВОСТИ КАК ФЕНОМЕН СОВРЕМЕННОСТИ
}

\begin{abstract}
Аннотация. В статье рассматривается феномен фейковых новостей. Авторы представляют краткий обзор наиболее актуальной литературы по этой теме. В качестве методологической основы выбран сравнительно-аналитический и классификационный пути исследования. Современное цифровое общество вступает в эпоху постправды, в которой фейковые новости начинают вытеснять обычные. В статье представлены классификационные критерии, характеристика и примеры различных видов фейковых новостей. В заключение авторы приводят аргументы, подтверждающие общественную опасность фейковых новостей и необходимость борьбы с ними, в т.ч. и на законодательном уровне.
\end{abstract}

Ключевые слова: фейк, постправда, социальные сети, пост, закон о фейковых новостях

Введение. Фейковые (от англ. fake - подделка, обман, ложь) новости и материалы заполоняют современное медиапространство и являются значимым фактором в распространении тех или иных мнений в СМИ и интернет-пространстве. Фейковые новости стилистически похожи на обычные, но отличаются от них полной или частичной недостоверностью. За последние 10 лет (особенно активно в 2013-2014 гг. - с начала украинских событий) фейковые новости как пожар охватили различные интернет-ресурсы, в частности социальные сети. В результате интернет-пользователи тысячами ставят лайки лживым сообщениям и постам. На смену простому «зомбоящику» пришел более сложный и изощренный «зомбоэкран» с клавиатурой.

Феномен фейковых новостей требует своего теоретического осмысления. Важно понять, какую угрозу обществу несут фейковые новости, как с ними бороться. Эти и другие вопросы волнуют общественные науки в эпоху постправды, как называют нашу современность [Макурин, Возмищева 2016]. Постправда - это состояние современного цифрового общества, в котором факты имеют меньшую ценность, чем вызываемые ими эмоции и реакции людей, общества. Аксиологически это означает, что субъективное - эмоции, оценки, реакции, личные убеждения - выглядит значимее, чем объективное - факты и явления. Например, человеку, убежденному в том, что правительство США a priori не может совершить преступление, невозможно при помощи фактов доказать обратное. В этих условиях точное описание фактов утрачивает свою подлинную ценность, зато возникает множество версий одних и тех же фактов, которые можно отнести к фейковым новостям.

Проблемой фейковых новостей интересуются ученые и журналисты, специалисты по информационной безопасности. К числу интересных исследований, вышедших в последние годы, можно отнести работы А.П. Суходолова, О.С. Иссерс и С.Н. Ильченко. В статье А.П. Суходолова представлены классификационные критерии и различные виды фейковых новостей [Суходолов 2017]. В работах О.С. Иссерс и С.Н. Ильченко обосновываются доказательства 
«органичности» феномена фейковых новостей в рамках современной массовой культуры [Иссерс 2014; Ильченко 2016]. Следовательно, делается вывод, бороться с фейковыми новостями можно бороться, но полностью искоренить их нельзя.

Pезультаты. Сущность фейковых новостей заключается в том, что они тоже являются «новостями», но новостями недостоверными в той или иной степени, обладающими признаками сенсационности и эксплуатирующими зачастую инстинкты и сферу бессознательного. Такие «новости» всегда будут иметь определенной успех у неискушенной публики. Причем успех фейковых новостей у массовой аудитории в большинстве случаев будет выше, чем новостей настоящих [Ильченко 2016: 15]. Фейковые новости креативны, сенсационны, привлекательны для массы людей своим зачастую пикантным характером и, следовательно, более интересны ей, чем тривиальные новости и факты. Причем у массовой аудитории, особенно в постсоветских странах, сильно убеждение, что в официальных новостях ей говорят не всю правду, а что-то скрывают (пример - события в Кемерово после пожара в торговом центре «Зимняя вишня»). Это следствие того, что в СССР средства массовой информации зачастую либо говорили часть правды, либо умалчивали и искажали факты (как пример - сообщения советской прессы после аварии на Чернобыльской АЭС и др.). Массовая аудитория на инстинктивном уровне зачастую ждет фейковых новостей (в прошлом эту функцию выполняли слухи) и получает их от недобросовестных поставщиков, в качестве которых могут выступать как юридические, так и физические лица [Иссерс 2014: 117-118].

Классификация фейковых новостей имеет определенный научный интерес. Фейковые новости могут отличаться большей или меньшей степенью недостоверности самой информации, места и времени описываемых в новости событий и обстоятельств, набором персонажей, описываемых в новостях, целями и задачами создания и распространения фейка, уровнем восприятия достоверности новости [Суходолов 2017: 95-96].

Фейковые новости по степени недостоверности информации могут быть разделены на три группы. В первую группу входят новости, ложные от начала и до конца. Например, летом 2018 г. некоторые новостные агрегаторы опубликовали «новость» о том, что правительство рассматривает проект отказа от пенсионного обеспечения россиян. Один человек сразу определит, что это классический фейк, а другой легко поверит в эту сенсационную «новость». Различие между этими людьми зависит от уровня интеллектуального и культурного развития.

Во вторую группу фейковых новостей входят новости, являющиеся частично ложными. На фоне достоверных событий, представленных выборочно, появляется откровенный фейк. В качестве примера можно привести распространение через социальные сети «новости» о числе жертв после пожара в ТЦ «Зимняя вишня» (г. Кемерово) в 2018 г. Этот фейк, распространяемый пранкерами (в т.ч. с территории Украины), эксплуатировал комплекс недоверия россиян к официальной информации, возникший еще в советском прошлом. Общественная опасность такого рода фейков велика: люди начинают волноваться, что власть их обманывает, и посредством призывов образуется гневная толпа, требующая правды и справедливости.

В третью группу фейковых новостей входят новости, искажающие суть реального события. Это могут быть фразы, цитаты, выдернутые из контекста или изложенные не целиком, а выборочно. С таким фейком бороться сложнее всего, на него могут поддаться даже искушенные люди. Однако по части не стоит судить о целом (философский постулат о соотношении целого и частей): по одной цитате не стоит преждевременно делать выводы о всей речи. 
В зависимости от достоверности места и времени происшедших событий фейки могут быть разделены на две группы [Суходолов 2017: 98-99]. К первой группе относятся «новости», имеющие отношение к событиям, происшедшим в другом месте. Так, в 2004 г. во время катастрофического цунами, обрушившегося на побережье Юго-Восточной Азии и острова Шри-Ланка, пошли сообщения о целом городе в Таиланде, смытом в океан, и о гибели тысяч туристов. Город на самом деле был смыт океанской водой, но находился он на побережье Индонезии, где практически не было иностранных туристов. Ко второй группе фейковых новостей можно отнести сообщения, имеющие под собой достоверную основу, но происшедшие ранее, т.е. в другое время. Например, в 2009 г. появились сообщения, что доллар вырастет в цене в 5-6 раз (как в 1998 г.), и многие россияне стали переводить рубли с депозитов в доллары, о чем спустя месяцы сильно пожалели. И здесь фейк, имевший, казалось бы, правдивую основу, имел отрицательные для общества последствия, в отличие от банков, заработавших на панической информации.

Фейковые новости могут также классифицироваться по степени восприятия достоверности информации [Суходолов 2017: 100-101]. В первую группу входят «новости», сомнений в фейковости которых не остается практически ни у кого. Например, это может быть сообщение, что сегодня на рассвете Землю (например, где-нибудь в районе Южной Америки) атаковали инопланетяне. Во вторую группу входят «новости», которые вызывают сомнения в их правдивости, и поэтому у потребителя возникает желание проверить их из других источников. Это может быть сенсационное сообщение о находке останков предполагаемого внеземного существа. В третью группу входят «сообщения», которые настолько похожи на правду, что сомнения в их достоверности мало у кого остаются. Например, журналист Максим Кононенко в 2017 г. в Фейсбуке опубликовал шутливый пост о том, что в США из романа «Унесенные ветром» решили убрать Р. Батлера, поскольку тот воевал на стороне конфедератов (в это время были волнения в Шарлотсвилле на почве сноса памятников конфедератам). Этому посту поверили, и он собрал тысячи лайков. Когда же Кононенко опубликовал извинение за шутку, Фейсбук посчитал его фейком и убрал 1 .

Выводы. Таким образом, фейковые новости имеют разнообразный характер и назначение. В силу своей сенсационной природы такие «новости» всегда будут востребованы немалой частью общества. Отличить объективные факты от фейка в некоторых случаях представляется затруднительным. В первую очередь необходимо критично относиться к информационным источникам, анализировать поступающую информацию, сопоставлять различные источники и делать самостоятельные выводы. Необходимо помнить, что эти выводы в любом случае будут детерминированы нашими убеждениями, опытом и мышлением.

Для общества и государства фейковые новости несут большую реальную и потенциальную угрозу. Люди достаточно легко верят самым невероятным слухам, лживым сообщениям и постам. Поэтому не случайно в марте 2019 г. Государственная дума приняла, а президент России подписал закон о фейковых новостях, по которому за первое нарушение - публикацию и распространение фейковой информации - физическое лицо штрафуется на сумму до 100 тыс. руб., а юридическое - до 500 тыс. руб. За повторное нарушение или за тяжелые последствия опубликования фейковой информации, влекущие за собой смерть человека или общественные беспорядки, наказание грозит быть более суровым. Общество и государство осознали, что пора противопоставить распростране-

\footnotetext{
${ }^{1}$ Голицина А. Журналисты помогут Фейсбук бороться с фейками. - Ведомости. 01.11.2017.
} 
нию лживых новостей меры на законодательном уровне. В ближайшее время этот необходимый закон пройдет проверку на работоспособность.

\title{
Список литературы
}

Ильченко С.Н. 2016. Фейковая журналистика как элемент современной шоу-цивилизации. - Известия Уральского федерального университета. Сер. 1. Проблемы образования, науки и культуры. Т. 153. № 22-3. С. 14-18.

Иссерс О.С. 2014. Медиафейки: между правдой и мистификацией. Коммуникативные исследования. № 2. С. 112-123.

Макурин А.И., Возмищева М.А. 2016. Некоторые итоги деятельности Б. Обамы. - Гуманитарные научные исследования. № 11. Доступ: http://human. snauka.ru/2016/11/17653 (проверено 30.03.2019).

Суходолов А.П. 2017. Феномен «фейковых новостей» в современном медиапространстве. - Евроазиатское сотрудничество: гуманитарные аспекты: материалы международной научно-практической конференции. Иркутск: Изд-во Байкальского государственного университета. С. 93-112.

KRASOVSKAYA Nataliya Rudolfovna, Cand.Sci. (Psych.), The Office of the State Duma of the Federal Assembly of the Russian Federation (1 Okhotny Ryad St, Moscow, Russia, 125007; goulina@gmail.com)

GULYAEV Andrei Anatol'evich, Cand.Sci. (Philos.), Associate Professor at the K.G. Razumovsky Moscow State University of Technologies and Management (the First Cossack University) (73 Zemlyanoi Val St, Moscow, Russia, 109004; andrey. gulyaev1966@yandex.ru)

YULINA Galina Nikolaevna, Cand.Sci. (Ped.), Associate Professor, Director of the Institute of Social and Humanitarian Technologies, K.G. Razumovsky Moscow State University of Technologies and Management (the First Cossack University) (73 Zemlyanoi Val St, Moscow, Russia, 109004; UlinaGN@mgutm.ru)

\section{FAKE NEWS AS A PHENOMENON OF MODERNITY}

\begin{abstract}
The article deals with the phenomenon of fake news. The authors present a brief review of the most relevant literature on this topic. The methodological basis of the paper is the comparative-analytical and classification ways of research. Modern digital society is entering the era of post-truth, in which fake news is beginning to displace conventional ones. The article presents the classification criteria, characteristics and examples of different types of fake news. In conclusion, the authors muster an arguments confirming the public danger of fake news and the need to combat them, including at the legislative level.
\end{abstract}

Keywords: fake, post truth, social networks, post, fake news law 